\title{
Determination of Environmental and Economic Benefits of Graphene-Coated PV Modules Through the School Building
}

\author{
Merve Tuna Kayilii*, Caner Yetis² \\ 1 Department of Architecture, Faculty of Architecture, Karabuk University, Kastamonu Yolu Demir Çelik Kampüsü, \\ 78050 Kılavuzlar, Karabük, Turkey \\ 2 Department of Architecture, Institute of Graduates Education, Karabuk University, Kastamonu Yolu Demir Çelik Kampüsü, \\ 78050 Kılavuzlar, Karabük, Turkey \\ * Corresponding author, e-mail: mervetunakayili@karabuk.edu.tr
}

Received: 25 June 2020, Accepted: 27 May 2021, Published online: 29 June 2021

\begin{abstract}
Graphene coatings, which have many applications in electronics and biomedical, show high performance even when applied at a few nanometers thickness, and have also been applied in solar systems. When graphene is applied to the glass surface of photovoltaic (PV) modules, they result in more energy recovery and lower cleaning service fees due to their features such as high permeability, hydrophobic self-cleaning, and low dust retention. In this study, it was determined how much energy gain and $\mathrm{CO}_{2}$ emission reduction could be achieved as a result of graphene-coating on PV modules compared to standard modules, and if PV modules are applied under Turkish conditions, the investment costs, payback period, and return on investment to the user after the payback period was determined. As a result of the calculations, although the initial investment cost of graphene coating is $0.78 \%$, more than the standard modules, it is concluded that it offers a lower payback period and high return on investment due to the amount of energy it produces, its ability to self-clean, and low dust retention.
\end{abstract}

Keywords

graphene coated PV module, $\mathrm{CO}_{2}$ emission, payback period, energy efficiency, economic performance

\section{Introduction}

Today, more than $40 \%$ of total energy use is due to the building sector in the European Union member states (European Commission Energy Department, 2020). Because of this consumption, which occurs above the level of sustainability, high energy consumption and the provision of this energy from fossil fuels are among the factors affecting the environmental problems arising from the built environment. As a result of satisfying energy needs from fossil fuels, environmental impacts such as climate change, acidification, photochemical ozone gas formation, and ecological poisoning occur. The most basic and effective way to eliminate these effects is to meet energy demand from renewable energy resources. When the energy crisis and climate change are considered, solar energy stands out in providing comfort such as heating, cooling, air conditioning, and lighting in the building sector. Photovoltaics (PVs), also known as "solar electricity" or "solar cells", which generate electrical energy from sunlight, were first researched by Becquerel in 1839, with modern PV cells (solar cells) developed in 1954 and used as an expensive electricity generator in space technology satellite vehicles (Erge and Sick, 1996; Markvart, 2000). Although electrical efficiency decreases with overheating in the modules featured, due to the increasing intensity of sunlight, more energy can be generated (Bedeloğlu et al., 2010). Furthermore, depending on the developments in technology, industrialisation in production and increased demand, they have been used in watches and calculators, street lighting, and since 1981, integrated into buildings (Çelebi, 2002).

By concentrating scientific research on nanotechnology and nanomaterials and transferring the gains to the industry, innovative materials and elements can be obtained. As a result of the integration of nanotechnology and nanomaterials into PV modules, significant improvements in photovoltaic systems can be achieved. When the literature and PV industry are examined, it can be seen that there are self-cleaning solar modules and "dye-sensitised" solar cells that use an organic dye monolayer to help absorb sunlight, 
much as plants do for photosynthesis (Alanbari et al., 2019). In addition, scientists from the Nano-Science Centre at the Niels Bohr Institut, Denmark and the Ecole Polytechnique Fédérale de Lausanne, Switzerland, have shown that a single nanowire can concentrate the sunlight up to 15 times the average sunlight intensity. This has resulted in a new type of highly efficient solar cell (Krogstrup et al., 2013). With these, the HZB Institute for Silicon Photovoltaics has shown that graphene holds its important properties when coated with a thin silicon film (Gluba et al., 2013).

Graphene, which resulted in the Nobel physics prize for Andre Geim and Konstantin Novoselov in 2010, is one of the allotropes of elemental carbon (carbon nanotube, fullerene, diamond) and is a single-layered version of carbon atoms in two dimensions. It has a carbon-carbon bond length of $0.142 \mathrm{~nm}$ (Singh et al., 2011; Slonczewski and Weiss, 1958). Its graphene structure is six times lighter than steel, and it has six times lower density but is six times stronger and capable of stretching 13 times more than steel. Graphene, which has at least ten times more mobility than silicon technology, is a breakthrough in many carbon-based areas with its very elastic and stable structure (Singh et al., 2011; Zhang et al., 2005).

Graphene has high electron mobility $\left(250000 \mathrm{~cm}^{2} / \mathrm{Vs}\right)$, thermal conductivity $(5000 \mathrm{Wm}-1 \mathrm{~K}-1)$, and $1 \mathrm{TPa}$ Young module at room temperature (Çetin, 2013; Singh et al., 2011). It exhibits higher electrical conductivity in supercomputers, is used in the formation of super-powerful composites, ultrathin and light aircraft, high-performance integrated circuits, and multiple new nanoelectronics devices; the next-generation PV modules have been realised with the thinnest, lightest, most flexible and conductive nanomaterial.

By coating PV modules with graphene, it is possible to increase the power of PV modules. A system's performance may decrease as a result of the increase in temperature caused by sunlight in PV modules. According to a study on this subject, the efficiency decreased by $1 \%$ for every $10^{\circ} \mathrm{C}$ temperature increase (Alaçakır, 1999). In graphene-coated modules, the module temperature was $1{ }^{\circ} \mathrm{C}$ lower on average $\left(\max 2{ }^{\circ} \mathrm{C}\right)(Z n s h i n e$ Solar, 2019). In addition, graphene coating glass reduces the risk of hot spots in modules and provides safer use with reduced fire risk.

The pollution of the module surface and dust accumulation are other important factors that reduce PV modules' efficiency (Eiffert and Kiss, 2000). Studies show that PV performance decreases by $3.5 \%$ due to pollution (Watt et al., 1999). Therefore, module surfaces need to be cleaned periodically to improve performance. Periodic cleaning is an additional cost in solar system operation. With a graphene coating on the PV module's glass surface, dust accumulation can be reduced, as shown in Fig. 1. In addition, graphene coating adds hydrophobic properties to the glass surface, cleaning itself with rain and quickly shedding the rain from the surface (Znshine Solar, 2019). In this way, cleaning costs can be significantly decreased by reducing the number of cleaning operations.

Currently, the graphene coat is applied to a single surface of PV modules; studies are continuing regarding covering both sides. The technical reason for applying graphene to PV modules is to increase the photoelectric conversion efficiency of solar cells by taking advantage of graphene's high thermal conductivity and light transmittance (AM1.5 transmittance is $94.05 \%$; visible light transmittance is $94.20 \%$ ) and thus reduce the return time of an investment. Energy production in graphene-coated PV modules is approximately $2 \%$ higher than in standard modules. It ensures the longevity of the coated PV modules due to their high resistance to high and low humidity $(5 \%-85 \%)$, temperature differences $\left(40{ }^{\circ} \mathrm{C}-85{ }^{\circ} \mathrm{C}\right)$, acid and UV rays (Znshine Solar, 2019). Table 1 shows a performance comparison of graphene-coated PV modules with standard modules that are not coated. The graphene coating can perform different light transmittance at different wavelengths suitable for PERC and Black silicon technology. It can be applied to a standard double glass or different solar modules, allowing it to be perfectly integrated into productivity-enhancing technologies.

Since the life of PV panels is about 25-30 years, life cycle analysis should be performed in addition to determining electricity production. Within this context, Farias-Rocha et al. (2019) conducted the life cycle cost analysis of grid-connected PV solar modules in the Philippines according to the principles of feed-in-tariff and net metering. In this study, payback periods were 4.1 years for feed-in-tariff and 7.8 years for net metering.

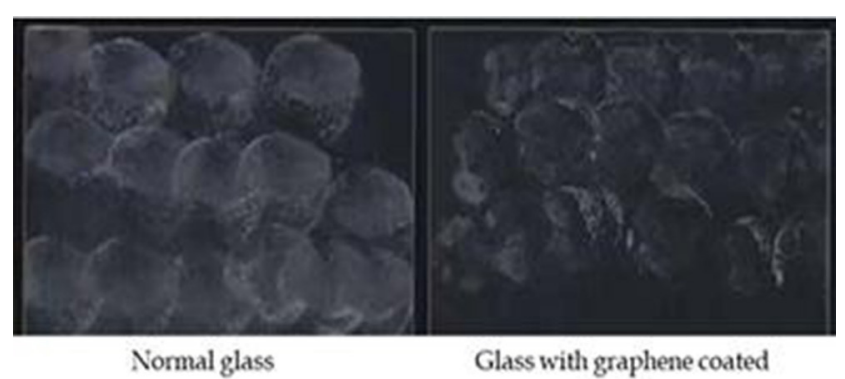

Fig. 1 Comparison of the dust accumulation of glass with graphenecoated and standard glass (Znshine Solar, 2019) 
Table 1 The comparison of the features of graphene-coated PV modules and regular PV modules (Znshine Solar, 2019)

\begin{tabular}{|c|c|c|}
\hline Features & Graphene-coated PV modules & Regular PV modules \\
\hline Transmittance & $94.2 \%$ & $93.70 \%$ \\
\hline Dust accumulation comparison & $\begin{array}{l}6.28 \mathrm{~g} / \mathrm{m}^{2} \text { (modules established outdoors for one } \\
\text { month) not easy to accumulate dust }\end{array}$ & $\begin{array}{c}13.82 \mathrm{~g} / \mathrm{m}^{2} \text { (modules established outdoors for one } \\
\text { month) easy to accumulate dust, }\end{array}$ \\
\hline Dust influence & $\begin{array}{c}2.85 \% \text { (same module, same quality and in same } \\
\text { environment) }\end{array}$ & $\begin{array}{c}8.52 \% \text { (same module, same quality and in the } \\
\text { same environment) }\end{array}$ \\
\hline Working temperature & lowers the temperature by $1{ }^{\circ} \mathrm{C}$ on average $\left(\max 2{ }^{\circ} \mathrm{C}\right)$ & cannot lower solar module temperature \\
\hline Operation and Maintenance & $\begin{array}{l}\text { reduces cleaning frequency of solar modules by } \\
\text { about } 30 \%\end{array}$ & \\
\hline Self-clean & $\begin{array}{l}\text { self-clean (super hydrophilic, allows water to flow } \\
\text { easily, organic materials can easily be broken down) }\end{array}$ & $\begin{array}{l}\text { has no self-clean feature (hydrophobic, water does not } \\
\text { flow easily }\end{array}$ \\
\hline Power generation & $2 \%$ higher & \\
\hline Degradation Rate & $\begin{array}{l}15 \% \text { for double glass graphene technology solar } \\
\text { modules in } 25 \text { years }\end{array}$ & $\begin{array}{c}19.32 \% \text { for single glass standard solar modules in } 25 \\
\text { years }\end{array}$ \\
\hline
\end{tabular}

Rajput et al. (2018) conducted actual field performance analyses of $3.2 \mathrm{~kW}$ capacity PV panels over a 30-year life span and determined a payback period as 3.6 years.

During the literature search on PV materials, we encountered three efficient materials that exhibit remarkable $\mathrm{PV}$ properties. These three materials are $\mathrm{TiO}_{2}$ nanoparticles, polyaniline and graphene (Nemade et al., 2018a; Nemade et al., 2018b). Among the directing polymers, for example, polyaniline (PANi), poly-pyrrole (PPy) and polythiophene (PTh), PANi has been broadly studied by researchers. In addition, there are many studies on PANi/ graphene composite based solar cells (Nemade et al., 2018a; Nemade et al., 2018b) and $\mathrm{TiO}_{2}$ /graphene composites in hybrid solar cells (Wang et al., 2014; Saleem and Habib, 2016). These studies are aimed at increasing photovoltaic and photocatalytic properties in solar cells. There is no study of the economic gains of graphene-coated modules in the literature.

In this study, however, the energy gains to be achieved by using graphene-coated PV modules and non-graphenecoated standard PV modules in the structure, the investment costs and payback period and environmental and economic gains during economic life were determined. It aims to determine the investment costs in Turkey, the payback period and environmental, economic, and energy gains by using graphene-coated PV modules and non-graphene coated standard PV modules in the structures. To compare graphene-coated PV modules (PV-G) with standard $\mathrm{PV}$ modules (PV-NG) in a simulation environment, a high school building in Safranbolu was selected for field research; and it was assumed that the modules would be integrated into the roof of the building. Afterwards, the amount of energy produced for the two module types, payback period and environmental and return on investment over the module life cycle, were analysed comparatively through the PV-grid connected system. Therefore, this study can provide researchers, designers, engineers and investors working on PV systems with versatile information on graphenecoated panels when selecting PV modules.

\section{Materials and methods}

\subsection{Module types}

ZNShine brand ZX series (ZXM6-LD72-375/P) $375 \mathrm{~W}$ power heat-reinforced double glass with graphene-coated (PV-G) and non-coated (PV-NG) modules were evaluated in the scope of the present study (Table 2). The requirement 
Table 2 Properties of selected module type (Znshine Solar, 2019)

\begin{tabular}{|c|c|c|}
\hline Properties & $\begin{array}{l}\text { ZXM6-LD72-375/M } \\
\text { (Regular) }\end{array}$ & $\begin{array}{l}\text { ZXM6-LD72-375/M } \\
\text { (Graphene coated) }\end{array}$ \\
\hline Module dimension & $1978 * 992 * 30 \mathrm{~mm}$ & $1978 * 992 * 30 \mathrm{~mm}$ \\
\hline Solar cells & Mono/156.75*156.75 mm & Mono/156.75*156.75mm \\
\hline Glass & $\begin{array}{l}2.0+2.0 \mathrm{~mm} \text { heat } \\
\text { strengthened glass }\end{array}$ & $\begin{array}{l}2.0+2.0 \mathrm{~mm} \text { heat } \\
\text { strengthened glass } \\
+ \text { graphene coating }\end{array}$ \\
\hline Weight (kg) & $25.5 \mathrm{~kg}$ & $25.5 \mathrm{~kg}$ \\
\hline Module efficiency (\%) & 19.11 & 19.11 \\
\hline $\begin{array}{l}\text { Nominal Power Watt Pmax } \\
\text { (W) }\end{array}$ & 375 & 375 \\
\hline $\begin{array}{l}\text { Open Circuit Voltage Voc } \\
\text { (V) }\end{array}$ & 48.3 & 48.3 \\
\hline $\begin{array}{l}\text { Short Circuit Current Isc } \\
\text { (A) }\end{array}$ & 9.97 & 9.97 \\
\hline $\begin{array}{l}\text { Maximum Power Voltage } \\
\text { Vmp (V) }\end{array}$ & 39.6 & 39.6 \\
\hline $\begin{array}{l}\text { Maximum Power Current } \\
\operatorname{Imp}(\mathrm{A})\end{array}$ & 9.47 & 9.47 \\
\hline Loss rate $(\%)$ & 2 & 1 \\
\hline
\end{tabular}

to meet the maximum amount of established power and the south roof area has been effective in determining the appropriate power for the modules. The south roof of the building and the shading factor stemming from the north roof were taken into account in the placement of photovoltaic modules.

\subsection{Safranbolu vocational high school building}

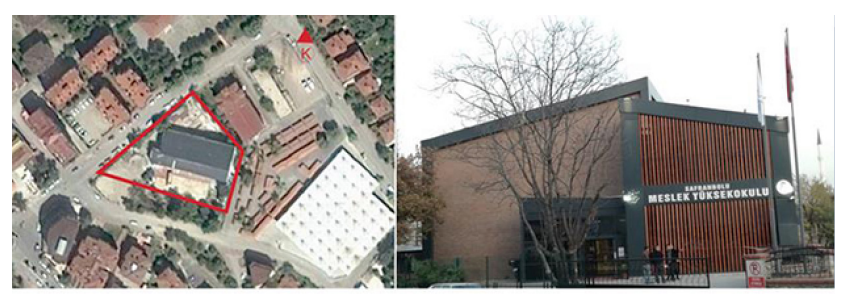

(a)

(b)

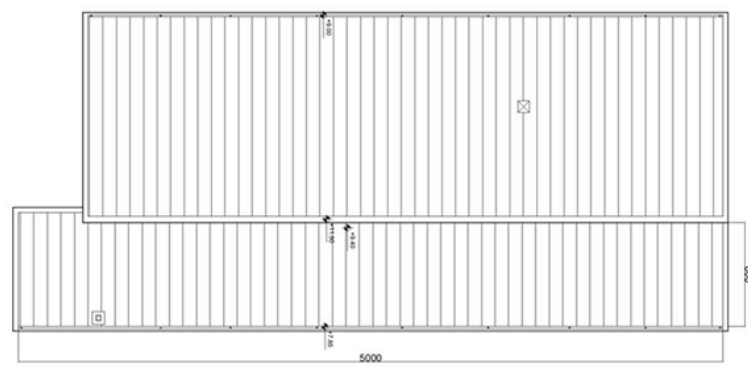

(c)

to a large number of workshop classes in the building, an intense energy requirement was observed due to the

Fig. 2 (a) SVHS settlement plan; (b) West elevation; (c) Roof plan 
devices used in the workshops. It can be said that integrating PV modules into the southern front of the structure is a very rational solution to provide this energy from renewable energy sources instead of fossil fuels.

The solar energy in the Black Sea region where the structure is located is reported as a maximum of $1704 \mathrm{kWh} / \mathrm{m}^{2} /$ year, while the average is $1086 \mathrm{kWh} / \mathrm{m}^{2} /$ year. The location of the SVHS building was determined from the Meteonorm Database as $1361 \mathrm{kWh} / \mathrm{m}^{2} /$ year (Meteotest, 2020). The sunshine duration for the same region is $1966 \mathrm{~h} /$ year. Monthly and annual spherical and diffuse irradiation values and temperature and air movement rate values for the building's location can be examined in Table 3.

\subsection{Simulation software}

In the research, $\mathrm{PV} * \mathrm{SOL}$ simulation software was used to analyze the energy performance of the PV modules that were coated with graphene and the uncoated double glass surfaces. The program can approximately present oneyear outcomes of the system to be established by hosting various power, voltage, and brand inverter and module information on its interface. The program obtains climate data from the Meteonorm Database.

\subsection{Data determination and acceptances}

If $\mathrm{PV}$ modules are integrated into the southern roof of the SVHS building, some building features and system to be established should be known; calculations should be made according to these features. One of the data obtained depending on the building is the determination of the estimated established power. For this purpose, the institution's management was contacted, and the actual electricity consumption value of the building for one year was determined as $79.06 \mathrm{MW} /$ year (Verbal Interview by Hacı Uçar, 2019). Data about the building were entered into the simulation software; following the selection of modules, the inverter model and power were selected. The number of inverters required for the solar system was proposed by the software, depending on the modules. The software suggested an inverter with the properties specified in Table 4 for this system. The maximum power the solar module could produce when the sun's rays arrived at the right angle and intensity was determined as $47.25 \mathrm{kWp}$.

Another datum obtained depending on the building is the surface azimuth angle, which is the angle between the building and the south. The surface azimuth angle for the SVHS building was calculated as $12^{\circ}$ using geometric data. For modules to be established on the southern roof of the building for high performance, the optimum module suitable for Turkey's location was decided according to plane tilt by using Eq. (1). The optimum module plane tilt obtained depending on Eq. (1) was calculated as $32.1^{\circ}$ (Eq. (2)). Since the SVHS southern roof has a $20^{\circ}$ tilt, the modules were decided to place on the roof with a $12^{\circ}$ tilt.

$$
\beta o p t=3.7^{\circ}+\left(\varphi^{*} 0.69\right),
$$

in where:

- $\beta$ opt: Optimum plane tilt

- $\varphi$ : latitude angle of building.

Accordingly, the foreseen optimum module plane tilt;

$$
\begin{aligned}
& \beta \text { opt }=3.7^{\circ}+\left(41.255^{*} 0.69\right), \\
& \beta \text { opt }=32.1^{\circ} .
\end{aligned}
$$

Table 3 Meteorological data from the SVHS area

\begin{tabular}{lcccc}
\hline Months & $\begin{array}{c}\text { Horizontal global irradiation } \\
\left(\mathrm{kWh} / \mathrm{m}^{2} . \mathrm{mth}\right)\end{array}$ & $\begin{array}{c}\text { Horizontal diffuse irradiation } \\
\left(\mathrm{kWh} / \mathrm{m}^{2} \cdot \mathrm{mth}\right)\end{array}$ & Temperature $\left({ }^{\circ} \mathrm{C}\right)$ & Wind velocity $(\mathrm{m} / \mathrm{s})$ \\
\hline January & 39.8 & 27.8 & 6.3 & 2.80 \\
February & 48.3 & 30.4 & 6.5 & 2.90 \\
March & 89.5 & 55.3 & 8.9 & 2.59 \\
April & 131.4 & 76.5 & 11.2 & 2.29 \\
May & 180.4 & 71.1 & 15.6 & 2.19 \\
June & 193.4 & 80.2 & 19.9 & 2.40 \\
July & 201.6 & 81.8 & 23.1 & 2.40 \\
August & 176.6 & 74.2 & 23.2 & 2.50 \\
September & 123.7 & 61.1 & 19.4 & 2.59 \\
October & 83.1 & 47.6 & 16.0 & 2.60 \\
November & 55.4 & 31.7 & 11.7 & 2.60 \\
December & 38.6 & 25.8 & 8.2 & 2.80 \\
Annually & 1361.8 & 663.5 & 14.2 & 2.6 \\
\hline
\end{tabular}


Table 4 Properties of the inventer

\begin{tabular}{lc}
\hline Inverter & \\
\hline Trade & String inverter \\
Type & SUN2000-40KTL \\
Dimensions (mm) & $550 \times 770 \times 270 \mathrm{~mm}$ \\
Weight $(\mathrm{kg})$ & 50 \\
DC max power (W) & 36700 \\
Max efficiency $(\%)$ & 98.8 \\
Operation temperature range & $-25^{\circ} \mathrm{C} \sim+60{ }^{\circ} \mathrm{C}\left(-13^{\circ} \mathrm{F} \sim+140^{\circ} \mathrm{F}\right)$ \\
Internal consumption at night & $<1 \mathrm{~W}$ \\
\hline
\end{tabular}

\subsection{Calculation of payback period and assumptions}

Within the scope of the study, the retail prices of the two modules were obtained from ZNShine Company. The price for the graphene-coated module (PV-G) was $0.265 \mathrm{USD} / \mathrm{W}$ (including shipping prices), while the price for the module without any coating on the glass surface (PV-NG) was $0.260 \mathrm{USD} / \mathrm{W}$ (including shipping prices). A quote was requested from Tureco Solar Company for inverter and installation, maintenance and cleaning services for local service procurement under Turkish conditions; the installation, maintenance and cleaning costs in the research were determined through this proposal. In converting energy acquisition to financial value, Turkish energy prices were taken into account and the unit price, including taxes and distribution charges for $1 \mathrm{KWh}$ of energy, was determined as 0.12 USD (The exchange rate was $1 \mathrm{USD}=5.74$ €). For this system to be established in Turkish conditions, the cleaning and maintenance service fees for one occasion were 525 USD and 871 USD, respectively, obtained from Tureco Solar Company.

In determining the payback period and Return on Investment (ROI) for the modules, two main and two sub scenarios were used. These scenarios are as follows:

1. The first scenario is the calculation of the payback period for (PV-G) and (PV-NG), which are obtained due to the economic comparison of initial investment costs and annual energy gains, which are the sum of installation and module fees. In this scenario, the payback period was calculated using Eqs. (3) and (4):

$e=E \times x$

in where:

- $E$ : annual energy gain (kWh)

- $e$ : annual economic energy gain (USD)

- $x$ : energy unit price (USD).
$P=i(\mathrm{USD}) \div e$,

in where;

- $P$ : payback period (year)

- $i$ : initial investment cost (USD)

- $e$ : annual economic energy gain (USD).

The second scenario is the calculation of the payback period as a result of comparing the total installation, module and system maintenance, repair and regular cleaning fees with the annual energy gains. However, the price of the cleaning service will be different for graphene-coated modules and non-graphene-coated modules. Therefore, four different assumptions were proposed for this scenario. These assumptions are as follows:

2. It is assumed that the cleaning service is performed twice a year for the module (PV-NGa) without any coating on the glass surface. Under the scenario a, the life span of the modules is regarded as 30 years. Maintenance and repair services are planned to be performed once per year. In this scenario a, the payback period was calculated using Eq. (5).

$P(P V-N G a)=(i+(30 \times m)+(60 \times c)) \div(30 \times e),(5)$

in where:

- $P$ : payback period;

- $i$ : initial investment cost;

- m: maintenance cost;

- c: cleaning cost;

- $e$ : annual economic energy gain

Due to the self-cleaning feature of the graphene-coated module (PV-G), the cleaning service will likely be less than the non-coated module. Therefore, three different assumptions were envisaged for the graphene-coated module, in which the cleaning service is performed once every year $\left(P V-G_{1 b}\right)$, once every two years $\left(P V-G_{2 b}\right)$, and once every three years $\left(P V-G_{3 b}\right)$. Under the scenario $b$, the life span of the modules was regarded as 30 years. It is foreseen that maintenance and repair services will be performed once a year. Payback periods for PV-G $G_{1 b}, P V-G_{2 b}$, and PV-G $G_{3 b}$ were calculated using Eqs. (6)-(8), respectively.

$$
\begin{aligned}
& P\left(\mathrm{PV}-\mathrm{G}_{1 \mathrm{~b}}\right)=(i+(30 \times m)+(30 \times c)) \div(30 \times \mathrm{e}), \\
& P\left(\mathrm{PV}-\mathrm{G}_{2 \mathrm{~b}}\right)=(i+(30 \times m+(15 \times c))) \div(30 \times \mathrm{e}), \\
& P\left(\mathrm{PV}-\mathrm{G}_{3 \mathrm{~b}}\right)=(i+(30 \times m)+(10 \times c)) \div(30 \times e),
\end{aligned}
$$


in where:

- $P$ : payback period;

- $i$ : initial investment cost;

- $m$ : maintenance cost;

- $c$ : cleaning cost;

- $e$ : annual economic energy gain.

\subsection{Calculating the ROI of the solar systems throughout their life cycles}

In calculating the economic gain that the systems established with PV-G and PV-NG will provide to their investors during their life cycle (30 years), 1. and 2. scenarios given in Subsection 2.5 were taken as a basis. Therefore, the economic gains provided to the users after the payback period (30-P) were determined based on three different scenarios. According to this, the total ROI of the solar system (PV-NG $\left.{ }_{\mathrm{a}}\right)$ established with graphene-uncoated modules were calculated by Eq. (9). The total ROI of the solar system established with graphene-coated modules with different cleaning periods $\left(P V-G_{1 b}, P V-G_{2 b}\right.$, $P V-G_{3 b}$ ) during its life cycle was calculated according to Eqs. (10), (11) and (12), respectively.

$$
\begin{aligned}
& \text { tROI }(\mathrm{PV}-N G a) \\
& =(((30-P) \times e)-((30-P) \times m)+((30-P) \times 2 \times c)), \\
& t R O \dot{I}\left(\mathrm{PV}-\mathrm{G}_{1 \mathrm{~b}}\right) \\
& =(((30-P) \times e)-((30-P) \times m)+((30-P) \times c)), \\
& \text { tROI }\left(\mathrm{PV}-\mathrm{G}_{2 \mathrm{~b}}\right) \\
& =((30-P) \times e)-((30-P) \times m)+((30-P) \times(c / 2)), \\
& t R O \dot{I}\left(\mathrm{PV}-\mathrm{G}_{3 \mathrm{~b}}\right) \\
& =(((30-P) \times e)-((30-P) \times m)+((30-P) \times c / 3)),
\end{aligned}
$$

in where:

- $t R O \dot{\text { : }}$ Total return on investment;

- $P$ : payback period;

- $m$ : maintenance cost;

- $c$ : cleaning cost;

- $e$ : annual economic energy gain.

\section{Results}

\subsection{Number of required modules and placement of modules}

In the placement of photovoltaic modules, the southern roof of the structure and the shading factor caused by the northern roof were taken into consideration. In this case, as can be seen in Fig. 3, 126 modules were placed on the surface of the south roof with 21 rows in the $\mathrm{x}$-direction and six rows in the y-direction. According to these rows, the operating system's efficiency is $83.1 \%$, and it can be said that it is of high performance.

\subsection{The comparison between the PV-G and PV-NG}

In this section, as a result of the integration of two different types of modules into the roof of the SVHS building, the amount of energy obtained from these two systems and the reduction of $\mathrm{CO}_{2}$ emissions, investment costs, payback period and $R O \dot{I}$ were analysed comparatively.

\subsubsection{Energy production and $\mathrm{CO}_{2}$ reduction}

As shown in Fig. 4, the energy generation obtained from the system, which consists of 126 pieces of $375 \mathrm{~W}$ modules integrated into the roof of the SVHS building, was determined as $61.91 \mathrm{MWh} /$ year and $61.19 \mathrm{MWh} /$ year for graphene-coated and non-graphene-coated modules, respectively. It was observed that approximately $1 \%$ more energy was obtained from graphene-coated modules. The system, created with graphene-coated modules, was calculated to prevent the release of 36.86 tons of $\mathrm{CO}_{2}$ emissions per year into the environment. Fig. 3 is 36.49 tons/ year for the solar system created with uncoated modules.

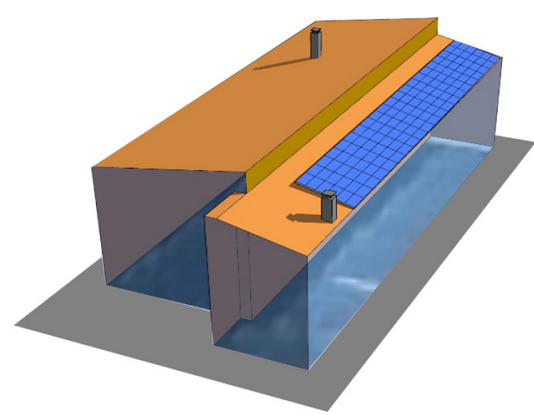

(a)

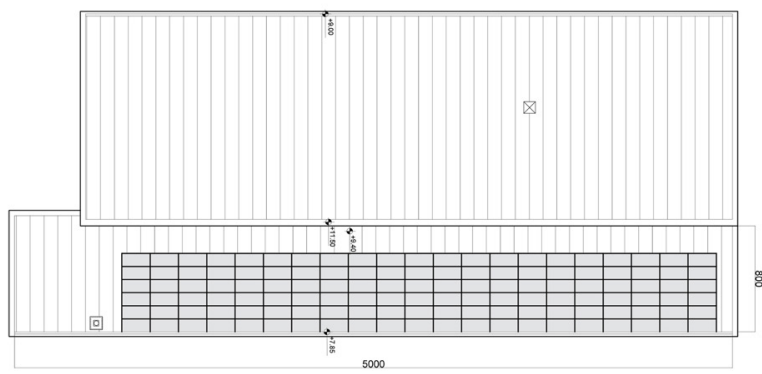

(b)

Fig. 3 (a) Placement of module on the roof (3d); (b) Placement of module on the roof $(2 \mathrm{~d})$ 


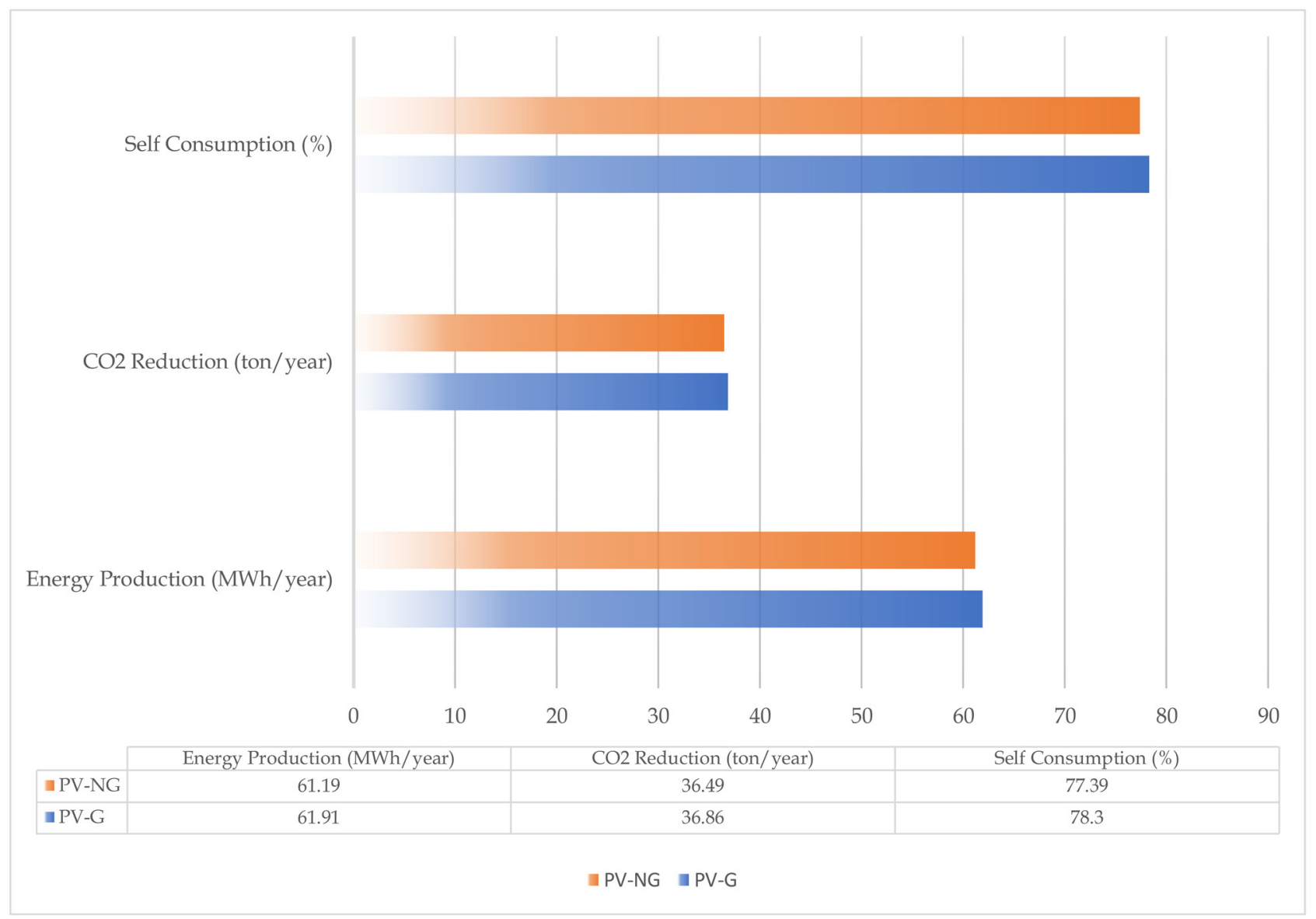

Fig. 4 Comparison with the PV-G and PV-NG with the context of energy production, $\mathrm{CO}_{2}$ reduction and self-consumption ratio

In this case, it was determined that 0.37 tons of $\mathrm{CO}_{2}$ per year would be prevented from being released into the atmosphere by using graphene-coated modules in the system. Also, 0.37 ton/year $\mathrm{CO}_{2}$ is substantial as it is equivalent to driving $905 \mathrm{~km}$ with an average passenger car (United States Environmental Protection Agency, 2019). Since the consumption of the SVHS building is $79.06 \mathrm{MWh} /$ year, the amount of energy obtained with the system established with graphene-coated modules can account for $78.3 \%$ of the consumption, compared to $77.39 \%$ in the system established with uncoated modules.

Fig. 5 shows the monthly energy production values of the system integrated into the roof surface with modules with two different surfaces. The highest energy gain was observed for both systems in July, with the minimum amount of energy generated by the system being $3.136 \mathrm{MWh} /$ year for graphene-coated modules in December. In uncoated modules, this production is $3.091 \mathrm{MWh} /$ year.

\subsubsection{Investment costs}

The module price-offer for PV-G and PV-NG was obtained from ZNShine, and the installation and design quote was obtained from Tureco. Investment costs include modules, inverters and shipping costs, project costs, consumables and labour costs required to install the system. As shown in Table 5, the initial investment cost of the system established with PV-G was 34.368 USD. The initial investment cost of the solar system established with PV-NG was calculated as 34.102 USD. Therefore, the difference between the initial investment costs of the systems established with two different modules based on graphene coating was 266 USD. This difference is $0.78 \%$ of the initial investment cost and is a low figure. This means that the graphene coating adds a $0.78 \%$ additional cost to the system.

\subsubsection{Payback periods}

The payback period for (PV-G) and (PV-NG) obtained from the economic comparison of the initial investment costs and annual energy gains, which are the sum of installation and module fees, are 4.62 and 4.64 years, respectively. The energy production of the graphene-coated module is $1 \%$ more than the non-graphene-coated module, which eliminates the difference of 266 USD in the investment cost and brings the investor a small additional 


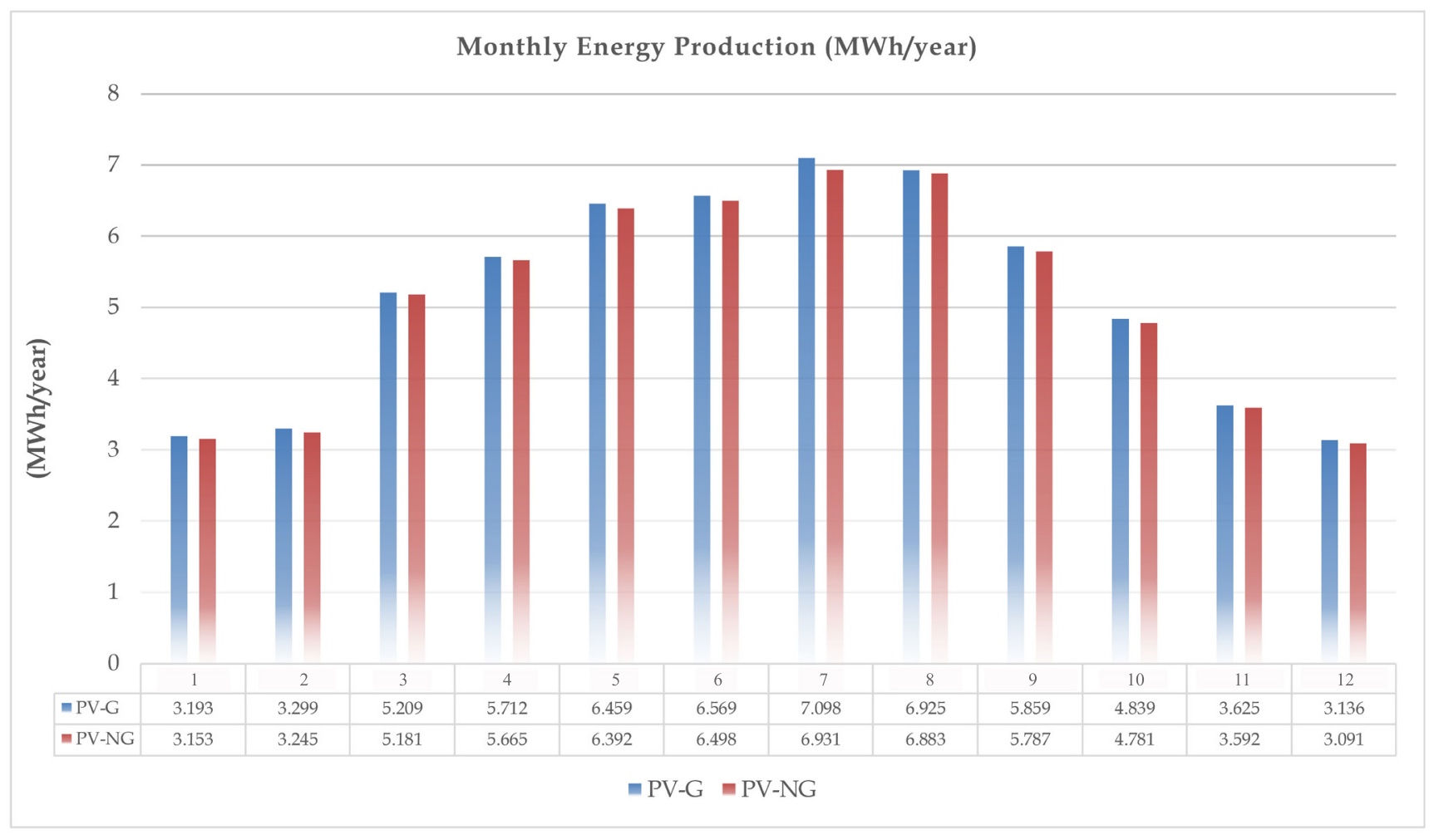

Fig. 5 Comparison with the PV-G and PV-NG with the context of monthly energy production

Table 5 Comparison of the PV-G and PV-NG in terms of the initial investment cost

\begin{tabular}{|c|c|c|}
\hline Equipment and labor & Price $\$$ for PV-G & Price $\$$ for PV-NG \\
\hline Project costs & 3052 & 3052 \\
\hline $\begin{array}{l}\text { Module (Znshine ZXM6- } \\
\text { LD72-375W) - shipping cost }\end{array}$ & 12511 & 12285 \\
\hline $\begin{array}{l}\text { Inverter (Huawei 2000-40 } \\
\text { KTL) and Smart Logger }\end{array}$ & 3250 & 3250 \\
\hline Building/Insurance & 250 & 250 \\
\hline Construction & 2000 & 2000 \\
\hline Cable channel and Pan & 270 & 270 \\
\hline Power Cables & 1743 & 1743 \\
\hline $\begin{array}{l}\text { Electrical distribution } \\
\text { equipment and assembly }\end{array}$ & 2300 & 2300 \\
\hline Grounding & 300 & 300 \\
\hline Mechanical labour cost & 1500 & 1500 \\
\hline Electrical labor cost & 1750 & 1750 \\
\hline Warning Sign & 200 & 200 \\
\hline Taxes & 5242 & 5202 \\
\hline Total & 34368 & 34102 \\
\hline Difference & $+266 / 0.78 \%$ & 0 \\
\hline
\end{tabular}


profit on an annual basis. Therefore, it was determined that graphene-coating shortened the system's payback period by approximately 0.02 years, or seven days, as a result of calculations made using Eq. (3).

The payback period for (PV-G) and (PV-NG) obtained by comparing the installation, module and total maintenance and cleaning fees of the system with annual energy gains were calculated separately for scenarios A and B using Eqs. (4) to (7) and the results are given in Table 6. As shown in Table 6, the payback period was calculated to be 6.8 years, taking into account the costs of the system established with graphene-uncoated PV modules for its life cycle. The increase in this number is due to the twice-yearly cleaning service fees. Thus, due to its self-cleaning and low dust retention, the payback period of the system established with graphene-coated PV ( $\mathrm{Sc} /$ $P V-G_{1 b}$ ) modules, where cleaning service is performed once a year, is 5.52 years and the payback period over its life span is 15.4 months shorter, although its investment cost is higher compared to the standard modules. As predicted, as the periods of cleaning services decreased, the payback period decreased as well. The payback periods were calculated as 4.95 and 4.76 years, in the case of cleaning services in graphene-coated modules performed once every two years and once every three years, respectively. This situation indicates that the solar system to be established provides a shorter payback period to its investors if the environment contains less dust and less air pollution.

\subsubsection{Economic gains}

Considering the cleaning and maintenance costs of systems established with PV-G and PV-NG, the ROI for the investor after the payback period (30-P) was determined as 125.765 USD for the solar system established with nongraphene-coated modules. As shown in Table 7, the ROI of the system established with graphene-coated PV modules as a net profit after the payback period is 147.692 USD for the PV- $\mathrm{G}_{1 \mathrm{~b}}$ scenario, 157.707 USD for the PV-G $\mathrm{G}_{2 \mathrm{~b}}$ scenario and 161.112 USD for the PV-G $\mathrm{G}_{3 \mathrm{~b}}$ scenario. Total economic gains are expected to increase depending on payback periods and cleaning service periods. In this case, although

Table 6 Payback period calculated for scenarios

\begin{tabular}{lcc}
\hline Scenarios & Payback period (years) & Payback period (months) \\
\hline PV-NG & 6.80 & 81.6 \\
PV-G & 5.52 & 66.2 \\
PV-G & 4.95 & 59.4 \\
PV-G $_{3 b}$ & 4.76 & 57.1 \\
\hline
\end{tabular}

Table 7 Total economic gain calculated for scenarios

\begin{tabular}{lc}
\hline Scenarios & Total $R O I$ (USD) \\
\hline PV-NG & 125.765 \\
PV-G & \\
PV-G & 147.692 \\
PV-G & 157.707 \\
\hline
\end{tabular}

the initial investment fee of the solar system established with graphene-coated modules is higher, it was observed that it offers greater economic benefits to its investors throughout its lifecycle.

\section{Conclusion}

Within the scope of the study, the effect of graphene coating applied to the module surface on annual energy production, $\mathrm{CO}_{2}$ reduction and payback period shortening and ROI were investigated. In the system established with graphene-coated PV modules (PV-G), approximately $1 \%$ more energy production and $\mathrm{CO}_{2}$ emission reductions were determined compared to the system established with nongraphene coated PV modules (PV-NG). The initial investment cost is 266 USD higher in the solar system established with PV-G due to graphene coating. The payback periods of the system were calculated for two different methods based on the initial investment cost and the cost of maintenance and cleaning services that stand out during the usage phase after the initial investment cost. In calculations based on the initial investment cost, the PV-NG system payback period was 4.64 years, and PV-G was 4.62 years. If the payback period is calculated by investment costs and maintenance and cleaning services required for its life cycle, the payback period increased to 6.8 years due to high cleaning fees in non-graphene-coated modules (PV-NG). Considering the ability of the system established with graphene-coated modules (PV-G) to clean itself and accumulate less dust on its surface, if a cleaning service is performed once every year $\left(P V-G_{1 b}\right)$, once every two years $\left(P V-G_{2 b}\right)$ and once every three years $\left(P V-G_{3 b}\right)$, the payback periods are determined as 5.52 years, 4.95 years and 4.76 years, respectively. The payback period of the system established with PV-G, which is planned to be cleaned once a year, is 15.4 months shorter than the payback period of the system established with PV-NG. However, the solar system established with PV-NG brings a 125.765 USD profit to its investors after the payback period; however, the profit of the solar system established with PV-G, which will be cleaned once a year, will be 147.692 USD after the payback period throughout the life cycle of the solar system, i.e. 21.927 USD increased profit. 
Nanocoatings have started to take their place in the construction and materials industry with their superior performance features and further development of nanotechnology. If the environment in which the solar system will be established contains less dust and less air pollution, graphene, which is used as a nanocoating in solar systems,

\section{References}

Alaçakır, B. (1999) "Didim'de Kurulan Şebeke Bağlantılı Güneş Pili Sisteminin Tanıtılması ve Performansının İncelenmesi", presented at Güneş Günü Sempozyumu, Kayseri, Turkey, June, 25-27, 1999. (in Turkish)

Alanbari, M. H., Cerpa, A., García-Pertusa, J. A. A., Ruız, S. (2019) "Nanotechnology Applied to Renewable Energy", The Online Journal of Science and Technology-October, 9(4), pp. 244-251. [online] Available at: https://www.tojsat.net/journals/tojsat/articles/v09i04/v09i04-02.pdf [Accessed:20 January 2020]

Bedeloğlu, A., Demir, A., Bozkurt, Y. (2010) "Fotovoltaik teknolojisi: Türkiye ve dünyadaki durumu, genel uygulama alanları ve fotovoltaik tekstiller" (Photovoltaic Technology: Situation and Applications in Turkey and in The World, General Application Fields and Photovoltaic Textiles), Tekstil Teknolojileri Elektronik Dergisi, 4(2), pp. 43-58. (in Turkish) [online] Available at: http://www. solar-academy.com/menuis/fotovoltaik-teknolojisi-T\%C3\%BCrkiye-d\%C3\%BCnya025044.pdf [Accessed: 19 December 2019]

Ceylan, İ., Gürel A. E. (2017) "Güneş Enerjisi Sistemleri ve Tasarımı" (The Systems and Design of Solar Energy), Dora Yayıncıllk, Burgaz, Bursa, Turkey. (in Turkish)

Çelebi, G. (2002) "Bina Düşey Kabuğunda Fotovoltaik Panellerin Kullanim İlkeleri" (Using Principles of Photovoltaic Panels on Vertical Building Envelope), Gazi Üniversitesi Mühendislik Mimarlık Fakültesi Dergisi, 17(3), pp. 17-33. (in Turkish) [online] Available at: https://dergipark.org.tr/en/pub/gazimmfd/ issue/6653/89023 [Accessed: 18 December 2019]

Çetin, H. (2013) "Grafen Temelli Gaz Sensörü Geliştirilmesi" (Development of a Graphene Based Gas Sensor), Tubitak Raporu, Yozgat, Turkey. (in Turkish)

Eiffert, P., Kiss, G. J. (2000) "Building-Integrated Photovoltaic Designs for Commercial and Institutional Structures: A Sourcebook for Architects", DIANE Publishing, Collingdale, PA, USA. [online] Available at: https://www.nrel.gov/docs/fy00osti/25272.pdf [Accessed: DATE (DAY MONTH YEAR)]

Erge, T., Sick, F. (1996) "Photovoltaics in Buildings - A Design Handbook for Architects and Engineers", Routledge, London, UK. https://doi.org/10.4324/9781315870106

European Commission Energy Department "In focus: Energy efficiency in buildings", [pdf] Energy Department, Brussels, Belgium. Available at: https://ec.europa.eu/info/sites/default/files/energy_climate_ change_environment/events/documents/in_focus_energy_efficiency_in_buildings_en.pdf [Accessed: 15 January 2021]

Farias-Rocha, A. P., Hassan, K. M. K., Malimata, J. R. R., SánchezCubedo, G. A., Rojas-Solórzano, L. R. (2019) "Solar photovoltaic policy review and economic analysis for on-grid residential installations in the Philippines", Journal of Cleaner Production, 223, pp. $45-56$.

https://doi.org/10.1016/j.jclepro.2019.03.085 offers its investors a shorter payback period. In addition to a short payback period, it is clear that it will play a role in reducing environmental impacts due to increased energy gain and emission reduction through its higher light transmission to solar modules.

Gluba, M. A., Amkreutz, D., Troppenz, G. V., Rappich, J., Nickel, N. H. (2013) "Embedded graphene for large-area silicon-based devices", Applied Physics Letters, 103(7), Article number: 073102. https://oi.org/10.1063/1.4818461

Krogstrup, P., Jørgensen, H. I., Heiss, M., Demichel, O., Holm, J. V., Aagesen, M., Nygard, J., Fontcuberta i Morral, A, (2013) "Singlenanowire solar cells beyond the Shockley-Queisser limit", Nature Photonics, 7(4), pp. 306-310.

https://doi.org/10.1038/nphoton.2013.32

Markvart, T. (2000) "Solar Electricity", Wiley, West Sussex, UK. https://doi.org/10.1109/JPHOTOV.2015.2479468

Meteotest "Meteonorm Software", [online] Available at: https://meteonorm.com [Accessed: 12 January 2020]

Nemade, K., Dudhe, P., Tekade, P. (2018a) "Enhancement of photovoltaic performance of polyaniline/graphene composite-based dye-sensitized solar cells by adding $\mathrm{TiO}_{2}$ nanoparticles", Solid State Sciences, 83, pp. 99-106.

https://doi.org/10.1016/j.solidstatesciences.2018.07.009

Nemade, K., Tekade, P., Dudhe, P. (2018b) "Strengthening of photovoltaic and supercapacitive properties of graphene oxide-polyaniline composite by dispersion of $\alpha-\mathrm{Al}_{2} \mathrm{O}_{3}$ nanoparticles", Chemical Physics Letters, 706, pp. 647-651.

https://doi.org/10.1016/j.cplett.2018.07.018

Rajput, P., Singh, Y. K., Tiwari, G. N., Sastry, O. S., Dubey, S., Pandey, K. (2018) "Life cycle assessment of the $3.2 \mathrm{~kW}$ cadmium telluride (CdTe) photovoltaic system in composite climate of India", Solar Energy, 159, pp. 415-422. https://doi.org/10.1016/j.solener.2017.10.087

Saleem, H., Habib, A. (2016) "Study of band gap reduction of $\mathrm{TiO}_{2}$ thin films with variation in $\mathrm{GO}$ contents and use of $\mathrm{TiO}_{2} / \mathrm{Graphene}$ composite in hybrid solar cell", Journal of Alloys and Compounds, 679 , pp. $177-183$.

https://doi.org/10.1016/j.jallcom.2016.03.240

Singh, V., Joung, D., Zhai, L., Das, S., Khondaker, S. I., Seal, S. (2011) "Graphene based materials: Past, present and future", Progress in Materials Science, 56(8), pp. 1178-1271.

https://doi.org/10.1016/j.pmatsci.2011.03.003

Slonczewski, J. C., Weiss, P. R. (1958) "Band Structure of Graphite", Physical Review, 109(2), pp. 272-279.

https://doi.org/10.1103/PhysRev.109.272

Uçar, H. (2019) "Verbal Interview", [verbal interview] Interviewed by Caner Yetiş, Safranbolu, Turkey.

United States Environmental Protection Agency "Greenhouse Gas Equivalencies Calculator", [online] Available at: https://www.epa. gov/energy/greenhouse-gas-equivalencies-calculator [Accessed: 02 January 2020] 
Wang, J., Liang, S., Ma, L., Ding, S., Yu, X., Zhou, L., Wang, Q. (2014) "One-pot synthesis of CdS-reduced graphene oxide 3D composites with enhanced photocatalytic properties", CrystEngComm, 16(3), pp. 399-405. https://doi.org/10.1039/c3ce41807c

Watt, M., Kaye, J., Travers, D., MacGill, I., Prasad, D., Thomas, P C., Fox, E., Jansen, S. (1999) "Opportunities for the Use of Building Integrated Photovoltaics in NSW", Photovoltaics Special Research Centre, University of NSW, Sidney, Australia.
Zhang, Y., Tan, Y. W., Stormer, H. L., Kim, P. (2005) "Experimental observation of the quantum Hall effect and Berry's phase in graphene", Nature, 438(7065), pp. 201-204. https://doi.org/10.1038/nature04235

Znshine Solar (2019) "Technical Report", Znshine Solar, Changzhou, China. 